PURBawidya: Jurnal Penelitian dan Pengembangan Arkeologi

p-ISSN: 2252-3758, e-ISSN: 2528-3618 @ Terakreditasi Kementerian Ristekdikti No. 147/M/KPT/2020

Vol. 10 (1), Juni 2021, pp 63 - 86 DOI: https://doi.org/10.24164/pw.v10i1.390

\title{
MITIGASI BENCANA DI SITUS CIDANGHYANG, PANDEGLANG: PENCEGAHAN TERHADAP POTENSI KERUSAKAN
}

\author{
Disaster Mitigation in Cidanghyang Site, Pandeglang: \\ Prevention of Potential Damage
}

\author{
Mohammad Ali Fadillah \\ Jurusan Pendidikan Sejarah, Fakultas Keguruan dan Ilmu Pendidikan \\ Universitas Sultan Ageng Tirtyasa \\ Jalan Ciwaru Raya No 25, Kota Serang 42117, Banten, Indonesia \\ e-mail:ali.fadilah@untirta.ac.id
}

Naskah diterima: 17-02-2021 - Revisi terakhir: 08-06-2021

Disetujui terbit: 28-06-2021 - Tersedia secara online: 30-06-2021

\begin{abstract}
The existence of the inscription is seen as the main indicator of Indonesia's entry into historical times. The seven Sanskrit inscriptions from Tarumanegara are written evidence of the establishment of a Hindu kingdom in western Java at the beginning of the fifth century AD under the rule of King Purnawarman. One of the inscribed stone relics known as the Munjul inscription, located far from the royal capital around the Citarum estuary between Jakarta and Bekasi, which testifies to the vastness of the territory and the influence of Tarumanegara rule. Carved on the top of andesite rock in situ at the Ci Danghyang meander, a tributary of the Ci Liman river that flows into the Sunda Strait, the Munjul inscription is in a vulnerable position to natural disasters, especially the unpredictable river overflows. Considering the importance of the Cidanghyang inscription as a cultural heritage that has been registered as RNCB 2016102501001351 , this study aims to reveal the natural phenomenon resent condition that has the potential to change, damage, and even eliminate objects and the surrounding environment. By identifying the impact of river overflow in recent years, it is hoped that this research can obtain field information about potential direct and indirect threats to cultural heritage. The results of these observations can provide a rational basis for formulating disaster mitigation policies on the Ci Danghyang river which has a direct impact on the inscription site as a preventive step in the framework of a cultural resource management system.
\end{abstract}

Keyword: Mitigation; Cidanghyang Inscription; Purnawarman; Tarumanagara

\begin{abstract}
Abstrak
Keberadaan prasasti dipandang sebagai indikator utama masuknya Indonesia ke zaman sejarah. Ketujuh prasasti berbahasa Sanskerta peninggalan kerajaan Tarumanegara menjadi bukti tertulis berdirinya sebuah negara bercorak Hindu di Jawa bagian barat pada awal abad V Masehi di bawah kuasa Raja Purnawarman. Satu dari ketujuh batu bertulis kerajaan Tarumanegara yang dikenal yang dengan nama Prasasti Munjul yang berada jauh dari pusat kerajaan, yaitu di sekitar muara Ci Tarum, antara Jakarta dan Bekasi, telah memberi kesaksian luasnya wilayah dan pengaruh kekuasaan Tarumanegara. Prasasti Munjul dipahat pada bagian atas batu andesit in situ di meander Ci Danghyang, anak Ci Liman yang mengalir ke Selat Sunda, berada pada posisi rentan terhadap bencana alam, terutama luapan sungai yang sulit diprediksi. Mengingat pentingnya Prasasti Cidanghyang sebagai cagar budaya yang sudah terdaftar dalam RNCB 2016102501001351 , penelitian ini bertujuan untuk mengungkapkan kondisi resen gejala alam yang berpotensi mengubah,
\end{abstract}


merusak, dan bahkan dapat menghilangkan objek beserta situs dan lingkungan sekitar. Dengan mengidentifikasi dampak luapan sungai beberapa tahun belakangan, diharapkan penelitian ini memperoleh informasi tentang potensi ancaman, baik langsung maupun tidak langsung terhadap cagar budaya. Hasil penelitian dapat menyediakan alasan rasional untuk merumuskan kebijakan mitigasi bencana di aliran Ci Danghyang yang berdampak langsung terhadap situs prasasti sebagai tindakan pencegahan dalam kerangka sistem manajemen sumber daya budaya.

Kata kunci: mitigasi; Prasasti Cidanghyang; Purnawarman; Tarumanagara

\section{PENDAHULUAN}

Gagasan untuk melindungi warisan budaya erat kaitannya dengan semangat penguatan identitas nasional. Dalam mewujudkan gagasan itu peran disiplin arkeologi sangat penting, baik di ranah akademik maupun manajemen pelestarian. Dengan perluasan teori dan metode arkeologi lintas bangsa, penelitian di Indonesia juga mengalami perkembangan, yang tidak hanya diorientasikan pada penemuan kembali akar sejarah, tetapi juga sebagai bagian dari perjuangan merebut kembali identitas budaya yang meredup selama periode kolonial. Namun, Indonesia yang lahir pasca Perang Dunia II masih menghadapi dualisme kepentingan: akademik dan politik. Dalam konteks itu pengelolaan sumber daya budaya menjadi jembatan yang menyatukan keduanya untuk mengejar tujuan yang sama, yaitu merumuskan apa yang harus dikaji dan dilindungi serta relevansinya dengan ideologi, hukum dan ekonomi.

Untuk mengatasi masalah itu diperlukan batasan tegas bahwa pelestarian harus ditentukan oleh relevansi ilmiah dan setiap bagian dari warisan budaya memiliki nilai tersendiri (Kristiansen 1990, 26). Pada prinsipnya pelestarian warisan budaya mencakup semua komponen sistem dalam semangat public archaeology yang meniscayakan sinergitas antara pelestarian budaya dan kebijakan pembangunan (Rieth 2007, 2--3). Sinergi itu hanya dapat berjalan apabila semua pihak memiliki kesamaan visi tentang nilai penting dari warisan arkeologi yang mencakup (1) kontribusinya bagi penguatan identitas bangsa, masyarakat, dan komunitas lokal; (2) mengandung seperangkat pengetahuan bagi masa depan bangsa; (3) merefleksikan ingatan kolektif pada suatu lanskap geografis. Ketiga hal itu menjadi alasan historis dan politis yang mengharuskan warisan arkeologi mendapat perlindungan dan menjadi tanggung jawab negara dan masyarakat (Kristiansen 1990, 27). Karena setiap zaman memiliki konsepsi sendiri tentang apa yang significance dan karena ilmu pengetahuan dibatasi oleh sejarah dan metodologi sendiri, perlindungan tidak dapat ditentukan hanya berdasarkan pada prioritas penelitian atau pertimbangan politik semata, tetapi juga mempertimbangkan kepentingan suatu bangsa dan berlaku bagi bangsa-bangsa lain di dunia.

Dalam dua dekade terakhir PBB melalui Unesco telah mengambil keputusan strategis agar setiap bangsa melestarikan warisan budaya. Terkait dengan program itu diperlukan rencana terpadu sesuai dengan semangat Cultural Resource Management (CRM). Dengan mempertimbangkan muatan nilai arkeologi, rencana aksi pengelolaan warisan budaya hendaknya mengacu pada manajemen baku CRM (Lubis, 2000; Kristiansen, 1990; Cleere, 1990, 5--6). Penerapan CRM sangat berkaitan dengan sasaran 
Agenda 21 Global, khususnya bidang kebudayaan yang diposisikan sebagai advisaory document; acuan bagi pemangku kepentingan untuk menyusun dan melaksanakan pembangunan sektor kebudayaan sebagai bagian tidak terpisahkan dari pembangunan berkelanjutan. Dokumen ini secara substansial memuat seperangkat saran dan rekomendasi bagi strategi dan kegiatan nasional pada sektor-sektor yang terkait dengan pembangunan bidang kebudayaan (Kangas, Anita. Duxbury, Nancy. Beukela 2017, 130).

Kebijakan badan dunia itu menunjukkan komitmen pelestarian cagar budaya secara global. Pengelolaan dan pemanfaatan warisan budaya dapat diperinci ke dalam empat isu pokok, yaitu situs atau objek arkeologi bernilai tinggi dikuasai negara untuk kepentingan publik, masyarakat luas sebagai the body of tax-payers, publik pariwisata berkontribusi melalui entrance fee, souvenir purchace dan guide-book; serta dalam kasus khusus cagar budaya memerlukan pembiayaan dari pemerintah atau badan-badan amal nonpemerintah (Cleere 1990, 9--10). Untuk merealisasikan upaya itu, diperlukan pola perencanaan, pengembangan, dan pengelolaan berbasis CRM dalam semangat merealisasikan Agenda 21 for culture (Agenda 21 Bidang Kebudayaan). Relevansi CRM dengan Agenda 21 for Culture terletak pada kebudayaan sebagai sumber daya pembangunan sekaligus juga tujuan pembangunan nasional. Rumusan itu merupakan hasil kesepakatan internasional untuk mengadvokasi peran budaya dalam pembangunan berkelanjutan. Program Culture 2015 Goal mengusulkan agar budaya diintegrasikan ke dalam Agenda PBB 2030 dalam pencapaian target Sustainable Development Goals (SDGs).

Berdasarkan usulan tersebut, budaya menjadi pilar konseptual keempat setelah lingkungan, sosial, dan ekonomi. Semangat itulah yang melahirkan perspektif baru dalam mengintegrasikan pelestarian warisan budaya dalam kebijakan pembangunan berkelanjutan di berbagai negara (Alisjahbana, Armida Salsiah., Murniningtyas, 2018, 226--28; Kangas, Anita. Duxbury, Nancy. Beukela 2017, 526; Poirier, D.A. \& Kenneth, 1995). Oleh karena itu, aplikasi model CRM dapat terlaksana dengan mempertimbangkan tujuh kondisi, yaitu (1) adanya kesadaran umum tentang nilai warisan arkeologi, (2) legislasi perlindungan dan penyelamatan, termasuk pendanaannya, (3) survei menyeluruh terhadap sumber daya arkeologi, (4) perencanaan untuk menghindari kerusakan warisan arkeologi, (5) operasi penyelamatan berupa kerusakan tidak dapat dihindari, (6) komunikasi, informasi, dan publikasi, serta (7) penyimpanan temuan dan dokumen yang aman. Dari ketujuh aspek tersebut, butir (4) dan butir (5) berkaitan langsung dengan penanganan risiko bencana (Trotzig 1990, 62).

Penanganan risiko bencana secara umum telah diatur di dalam Undang-Undang Nomor 24 Tahun 2007 tentang Penanggulangan Bencana, yang pelaksanaannya berpedoman pada Peraturan Pemerintah Nomor 21 Tahun 2008 tentang Penyelenggaraan Penanggulangan Bencana. Maka, dalam hal mitigasi bencana terhadap cagar budaya, regulasi itu menjadi acuan umum, sedangkan secara khusus hal itu berpedoman pada regulasi lex spesialis (ketentuan khusus), yaitu Undang-Undang Nomor 11 Tahun 2010 tentang Cagar Budaya yang menyatakan bahwa mitigasi relevan dengan klausul 
pelestarian berupa perlindungan, pengamanan, dan penyelamatan yang dilakukan sebelum cagar budaya mengalami kerusakan akibat bencana (Chandra 2018, 5--8).

Di beberapa negara juga terdapat regulasi serupa, tetapi dalam banyak hal belum memadai untuk diterapkan. Salah satu penyebabnya adalah karena kurangnya informasi berkenaan dengan warisan budaya, baik substansi maupun sebarannya sehinnga menjadi kendala dalam menyiapkan perencanaan. Lebih dari itu, permasalahan yang ditemukan di lapangan sering tidak terduga. Mengingat kondisi eksisting warisan budaya terus berubah, survei arkeologi harus dibarengi dengan identifikasi lingkungan yang berpotensi merusak. Menurut Gustaf Trotzig (1990, 62--63), kendala yang dihadapi dalam menyusun perencanaan mitigasi antara lain kurangnya informasi yang menyulitkan rencana perlindungan, pengabaian warisan budaya dalam pembangunan, penyelamatan hanya dapat dilakukan pada sisa-sisa arkeologi dan bergantung pada tersediaan anggaran, serta kesulitan menemukan lokasi yang sesuai untuk menyimpan temuan saat penyelamatan.

Jika negara-negara di Eropa dan Amerika sudah menerapkan CRM sejak tahun 1980-an, Indonesia baru mulai menerapkan CRM tahun 1990-an, tetapi dalam perjalanannya, aplikasi CRM masih terus dalam penyempurnaan dalam konsep dan model, termasuk mengintegrasikan dimensi-dimensi baru CRM ke dalam kinerja arkeologi (Sulistyanto 2009, 29). Itu sebabnya dalam praktik, langkah-langkah manajemen kerap menemui banyak kesulitan. Kasus pengelolaan kompleks Borobudur, Prambanan dan Sangiran merupakan best practice dalam CRM nasional, sementara di tempat lain: kompleks situs Trowulan (ibu kota Majapahit) dan Banten Lama (ibu kota Kesultanan Banten) misalnya, kendati terus menjadi subjek revitalisasi, lokasi tersebut masih menghadapi beberapa persoalan yang dipicu oleh faktor nonarkeologis (Supratikno Rahardjo, Tawalinuddin Haris, Kresno Yulianto 2011; Yogaswara dan Suartina 2014).

Oleh karena itu, penerapan CRM di beberapa situs atau cagar budaya yang terpilih mestinya menjadi model yang dapat direplikasikan ke lokasi dan objek lain yang berbeda substansi dan lingkungannya. Dalam proses input, output, dan outcome hal itu dapat dideteksi dengan Standard Operational Prosedure, tetapi masalahnya adalah kerap terjadi bias dalam mencapai target manfaat dan dampaknya yang sukar diukur dari indikator public accountability. Di luar ketiga model keberhasilan tersebut, kenyataannya banyak situs dan objek arkeologi yang masih 'menderita', artinya tetap rentan terhadap bencana alam dan sosial.

Kasus Banten Lama, ibu kota Kesultanan Banten (abad XVI--XVII) menjadi contoh kekosongan mitigasi cagar budaya. Sedimentasi yang diakibatkan oleh sungaisungai yang bermuara di Teluk Banten merupakan salah satu penyebab kemunduran fungsi ekonomi dan politik kota tersebut, bahkan hingga sekarang (Solihuddin, Tubagus. Prihantono, Joko. Mustikasar, Eva. Husrin 2020, 73--85). Hal itu akan sangat berdampak pada program pelestarian situs perkotaan Banten Lama yang sejak 2018 dilakukan penggalian kembali jaringan kanal sekitar ibu kota. Kasus di Kalimantan Selatan, sekitar muara sungai Martapura, juga menghadapi ancaman langsung dari luapan Sungai Barito. Setidaknya kompleks makam dan Masjid Sultan Suriansyah (Abad XVI--XVII) di 
kompleks Situs Kuin berada dalam kondisi rentan banjir. Upaya mitigasi telah dilakukan dengan merevitalisasi fungsi vegetasi di kompleks Situs Kuin (Rahmani dan Caesarina 2020, 84--85). Kasus Prasasti Ciaruteun adalah contoh relevan dari penyelamatan yang belum menerapkan model CRM. Terletak di Ci Aruteun sekitar $19 \mathrm{~km}$ barat laut kota Bogor, prasasti itu ditemukan pada tahun 1863, tetapi akibat banjir besar tahun 1893 batu prasasti ini terhanyutkan beberapa meter dan bidang tulisnya berada bagian bawah. Baru tahun 1903 prasasti dipindahkan ke tempat semula. Kemudian, pada tahun 1981 Direktorat Perlindungan dan Pembinaan Peninggalan Sejarah dan Purbakala mengangkat dan memindahkannya ke tempat yang terlindung (Zahorka 2007).

Berkaitan dengan topik situs prasasti Purnawarman, publik ilmiah telah mengetahui pentingnya sejarah awal berdirinya Tarumanegara di Jawa bagian barat yang mendapat pengaruh India setelah Kutai di Kalimantan Timur. Prasasti-prasasti Purnawarman sebagian besar ditempatkan di aliran sungai. Kecuali prasasti Ciaruteun yang telah diselamatkan, prasasti di Muara Cianten dan Cidanghyang masih rentan bencana. Apabila prasasti Cianten dalam posisi relatif terlindung, prasasti Cidanghyang, yang pernah dibaca oleh J.G. de Casparis dan Boechari pada tahun 1954 (Damais, 1967) membutuhkan perhatian khusus karena prasasti itu merepresentasikan teritori jauh Tarumanegara. Pada Februari 2017 dan Oktober 2020 situs Cidanghyang dalam kondisi relatif terlindung, tetapi oleh karena letaknya masih berada di aliran sungai, banjir dan longsor menjadi ancaman potensial. Maka upaya mitigasi pada situs dan kawasannya perlu mendapat perhatian. Pola penggunaan lahan yang cepat dan meluas sepanjang DAS Ci Liman dan Ci Danghyang secara tidak langsung akan memberikan dampak pada daerah sekitarnya (Kristofery, Leonard. Murtilaksono, Kukuh. Baskoro 2019, 66--71).

Didasarkan asumsi bahwa warisan budaya sebagai bagian penting dari kesadaran nasional dan juga media pembelajaran, upaya perlindungan benda budaya, situs, beserta lingkungannya memerlukan strategi yang tepat, yaitu mencakup legalitas, kelembagaan riset, dan agenda konservasi. Dengan sumber daya arkeologi yang didukung oleh upaya perlindungan dan pemeliharaan secara nasional, Indonesia mempunyai tempat pertama dalam bidang ini di antara negara-negara ASEAN (Guillot 1995, 29). Namun, masih banyak hasil riset belum diikuti upaya perlindungan dan pemeliharaan semestinya, terlebih situs yang berada jauh dari jangkauan peneliti dan masyarakat, padahal nilai historis dan bobot pengetahuannya amat penting dalam upaya penggalian sumber sejarah dan merekonstruksi kebudayaan masa lampau di Indonesia.

Dalam hal ini beberapa prasasti yang diterbitkan oleh Purnawarman dapat dijadikan contoh, khususnya prasasti batu pada bagian hulu sungai. Jawaban kunci terletak pada kepekaan memahami permasalahan: bagaimana kondisi terkini situs prasasti Cidanghyang? Sejauh manakah gejala alam memengaruhi kondisi prasasti? Bagaimana upaya mitigasi bencana bagi kelestarian objek beserta situs dan lingkungannya? Peristiwa yang menimpa Prasasti Ciaruteun menjadi pelajaran berharga karena pemindahan ke tempat aman dilakukan setelah terdampak, artinya upaya mitigasi belum diterapkan pada waktu itu. Sudah tentu upaya itu tidak paralel dengan manajemen sistem, mengingat akibat yang ditimbulkan dapat membahayakan kondisi fisik dari objek, maka menemukan 
solusi juga merupakan bagian dari Disaster Risks Management (DRM) dalam CRM yang terintegrasi sebagai upaya pengurangan risiko atas bencana yang sulit diduga.

Permasalahan tersebut harus dilihat sebagai isu strategis dalam kerangka CRM yang salah satu aspeknya adalah pendataan yang tidak hanya terfokus pada objek arkeologi, tetapi juga lingkungan sekitarnya. Tindakan pengurangan risiko bencana sangat diperlukan untuk menjamin kelestariannya. Kasus yang diangkat adalah Prasasti Cidanghyang, yang juga terletak di sungai (Gambar 1). Beberapa informasi lisan dan pengamatan langsung menunjukkan gejala alam yang dapat memengaruhi posisi dan keberadaan prasasti. Hanya saja hingga saat ini belum ada ukuran menurut skala risikonya: aman, rentan rawan, atau rawan bencana. Untuk mengetahui hal itu penelitian ini mencoba untuk menyelidiki gejala-gejala tersebut dan mengetahui apakah CRM sudah diterapkan ataukah masih menggunakan cara konvensional, seperti pada umumnya yang diterapkan di Indonesia?

\section{METODE}

Permasalahan yang telah dipaparkan sebelumnya mengandung dua faktor dominan yang dioperasikan dalam penelitian kualitatif ini. Pertama adalah nilai penting apa, dapat disebut the importance of object atau dalam kategori particular importance for art history yang diperoleh dari prasasti (Griffiths 2014, 56). Kedua adalah tindakan apa untuk merawat nilai humanitas yang terkandung pada material arkeologi. Sejak penemuan tahun 1947 kondisi batu prasasti telah mengalami perubahan fisik, terutama pelapukan dan keausan aksara (Gambar 2). Selama kurang dari empat dasawarsa (1947-1985) situs ini rentan rusak karena setiap musim hujan luapan sungai merendam prasasti setinggi 1,6 m. Masalahnya lagi, bersama air ikut hanyut material batu dan batang pohon besar menerjang prasasti. Patahan di bagian atas batu prasasti kemungkinan disebabkan benturan keras saat dilanda banjir.

Untuk menjawab permasalahan di atas, diperlukan asumsi dasar agar diperoleh data yang relevan. Pertama, adanya lembaga pelestarian yang dapat memantau perubahan-perubahan pada objek dan situsnya. Kedua, gejala alamiah di hulu sungai dan perbukitan sekitar dapat memengaruhinya. Ketiga, dengan mengamati tanggul dan cungkup pada lokasi prasasti tampaknya konservasi masih bersifat konvensional. Penelitian dilakukan dengan beberapa cara. Langkah awal adalah melakukan studi kepustakaan untuk mengetahui derajat kepentingan prasasti-prasasti Purnawarman, salah satunya di hulu Ci Danghyang. Secara spesifik Noorduyn dan Verstappen (1972) mengungkapkan pentingnya Prasasti Tugu sebagai bukti aktivitas pengaturan air sungai di ibu kota untuk menghindari banjir, sebagai koreksi atas tafsir Coedes yang mengaitkannya dengan pekerjaan irigasi (G. Coedès 1964, 54). Akan tetapi, secara umum, kajian atas Tarumanegara oleh (Kulke 1989) menempatkan prasasti-prasasti itu sebagai bukti keberadaan negara awal berkonsep India (Early Indianized State). Terakhir, bersumber pada studi Nadine Dalsheimer dan Pierre-Yves Manguin dalam kerangka studi kota-kota awal di Asia Tenggara, Tarumanegara mewakili keberadaan negara terawal pada abad IV dan V Masehi yang berbasis pada perdagangan (Dalsheimer dan Manguin 
1998); menguatkan adanya negara dalam pengertian kota terpusat beserta daerah taklukan (Wessing 2011).

Tahap berikutnya adalah observasi lapangan, dengan pengamatan terperinci pada objek, situs, dan lingkungan sekitar untuk mengetahui kondisi topografi dan beberapa gejala alamiah pada aliran sungai, yang memungkinkan peneliti dapat mempelajari berbagai fakta baru (Moleong, 2005). Langkah terakhir adalah melakukan wawancara untuk melengkapi informasi dari juru pelihara dan beberapa cendekiawan, pemerhati budaya, dan warga desa sekitar situs. Cara ini ditujukan untuk memperoleh informasi verbal dan berkaitan dengan pengetahuan dan pengalaman akademis dan teknis serta persepsi publik atas keberadaan Situs dan Prasasti Cidanghyang melalui komunikasi langsung dan kuesioner.

Kuesioner didasarkan pada tiga isu pokok, yaitu (1) potensi ancaman terhadap cagar budaya, (2) pemahaman regulasi cagar budaya, dan (3) pentingnya cagar budaya bagi masyarakat sekitar. Isu pertama ditujukan kepada akademisi yang mewakili keahlian arkeologi dan sejarah masing-masing dua orang dari Tim Ahli Cagar Budaya Banten dan dua orang dari Balai Pelestarian Cagar Budaya (BPCB) Banten. Isu kedua dan ketiga ditujukan kepada masyarakat sekitar situs yang terdiri atas perangkat desa, tokoh masyarakat, dan mahasiswa-pelajar setempat berupa pilihan ganda. Dari total 30 responden, ketiga kelompok tersebut dipilih secara acak, masing-masing 10 responden. Sementara itu, informasi tentang perencanaan, pelaksanaan, dan evaluasi pekerjaan konservasi dan konstruksi diperoleh melalui wawancara langsung dengan pemangku kepentingan, yaitu pegawai BPCB Banten dan Dinas Pendidikan dan Kebudayaan Kabupaten Pandeglang.

\section{HASIL DAN PEMBAHASAN \\ Persepsi Masyarakat}

Dalam konsep CRM keterlibatan masyarakat sangat diperlukan karena mereka adalah pewaris sesungguhnya. Relasi emotif antara objek dan manusia dapat dilihat dari awareness of the past. Adanya anggapan the past is a living component of present-day life merupakan motif psikologis untuk membangun identitas kolektif. Jika itu menjadi media untuk sens of belonging to a place or tradition, secara teoretis sikap dan tindakan masyarakat tidak berseberangan dengan pelestaria budaya. Hasil kuesioner terhadap tiga puluh responden acak penduduk sekitar menunjukkan kecenderungan ke arah itu. Untuk mengetahui persepsi masyarakat terhadap keberadaan prasasti, pertanyaannya terdiri atas tiga aspek, yaitu (1) pengetahuan dan pemahaman tentang regulasi cagar budaya, (2) anggapan terhadap keberadaan prasasti, dan (3) visitasi situs Prasasti Cidanghyang sebagai salah satu destinasi wisata budaya.

Berkenaan dengan aspek pertama diketahui bahwa sebagian besar responden kurang mengetahui dan belum memahami regulasi, khususnya kandungan UndangUndang No. 11 Tahun 2010 tentang Cagar Budaya. Kurangnya pemahaman berkorelasi dengan ketidaktahuan tentang peran masyarakat dalam melestarikan cagar budaya dan karenanya hal itu memengaruhi tindakan yang dilakukan apabila terjadi kerusakan situs 
dan prasasti. Dari lima pertanyaan yang diajukan tentang bagaimana tindakan yang harus dilakukan apabila terjadi bencana di sekitar situs prasasti, diperoleh jawaban dominan bahwa masyarakat akan melaporkan kepada pihak berwajib jika terjadi kerusakan akibat bencana ataupun perilaku manusia.

Aspek kedua tentang pengetahuan dan persepsi masyarakat akan pentingnya prasasti. Diperoleh jawaban bahwa sebagian besar responden belum mengetahui isi prasasti. Responden yang mengetahui isi prasasti menyatakan informasi diperoleh dari internet dan bersumber dari buku. Untuk pertanyaan apakah prasasti penting, seluruh responden memberikan jawaban penting. Persepsi itu berkorelasi langsung dengan anggapan bahwa prasasti juga bermanfaat bagi masyarakat. Sejalan dengan anggapan tersebut, seluruh responden memberikan jawaban merasa bangga dengan keberadaan prasasti di desa mereka. Artinya, meskipun sebagian besar belum mengetahui isi prasasti, keberadaan prasasti dianggap signfikan dan membangkitkan rasa bangga bagi warga setempat.

Aspek ketiga berkenaan dengan situs sebagai salah satu destinasi wisata. Berdasarkan pertanyaan yang diajukan diperoleh jawaban bahwa kunjungan ke situs prasasti dalam lima tahun terakhir terus meningkat. Sebagian besar pengunjung berasal dari luar desa dan kota lain, didominasi oleh siswa dan mahasiswa, dan hanya 10\% masyarakat umum. Waktu kunjungan tertinggi dilakukan pada hari libur secara berkelompok. Mengenai tujuan dan kegiatan yang dilakukan di lokasi, sebagian besar didorong oleh rasa ingin tahu melalui aktivitas rekreasi di lokasi prasasti untuk durasi 1-5 jam.

Mengacu pada data yang diperoleh dari kuesioner di atas, dapat disimpulkan bahwa sebagian besar penduduk desa masih menganggap penting, bahkan merasa bangga dengan keberadaan prasasti meskipun belum memahami sepenuhnya kandungan historisnya. Berkenaan ancaman terhadap kelestarian, penduduk mengetahui bahwa hal itu disebabkan oleh luapan Ci Danghyang, terutama pada musim hujan, tetapi tidak mengetahui tindakan apa yang harus dilakukan, kecuali melaporkan kejadiannya kepada pihak berwajib. Berdasarkan kuesioner tersebut, persepsi masyarakat akan keberadaan situs dan prasasti Cidanghyang merupakan modal sosial bagi upaya pelestarian warisan budaya. Namun, partisipasi masyarakat dapat lebih ditingkatkan ke arah mitigasi bencana yang didasarkan pada dua faktor, yaitu peningkatan pemahaman akan nilai historis dari prasasti dan peningkatan pengetahuan bahwa longsor dan luapan sungai terjadi sebagai akibat penggunaan lahan tanpa memperhatikan daya dukung lingkungan di perbukitan sekitar dan sepanjang hulu Ci Danghyang.

\section{Pentingnya Prasasti Purnawarman}

Sejak penemuan pertama paruh kedua abad XIX cukup banyak ahli yang mengkaji keberadaan Tarumanagara (Vogel 1925; Chhabra 1965), terutama didasarkan pada dua sumber paralel: teks prasasti dan sumber asing (China dan India). Isu paling mutakhir diajukan oleh Anton O. Zakharov (2019), dalihnya memeriksa kembali kajian teoretis atas prasasti-prasasti tertua di Asia Tenggara, khususnya yang terasosiasi dengan 
Raja Mulawarman dan Purnawarman, berkenaan dengan konseptualisasi unit politik awal dalam historiografi Asia Tenggara yang masih silang pendapat, antara kelompok yang menekankan ciri-ciri lokal dan yang mengikuti gagasan mandala Wolters, Zakharov —dipengaruhi pemikiran P. Y. Manguin bahwa kekuasaan politik pada awal abad Masehi masih menunjukkan watak the amorphous nature of maritime polities dan bahwa negara adalah sebuah proses - menyatakan I would say the process is a sequence of changes of various states/conditions, and of states of changes (Manguin 2002; Zakharov 2019, 218). Namun, ia tidak sepenuhnya menolak penggunaan istilah negara yang lebih netral dengan menyebutnya kingdom dan empire, merujuk pada entitas politik awal di Asia Tenggara (Glover dan Bellwood 2004). Pertanyaannya adalah argumen apa yang dapat diterima untuk melabeli negara pada unit-unit politik dari abad IV dan V Masehi.

Beberapa sejarawan menganggap negara-negara di Asia Tenggara terbangun oleh jaringan perniagaan Asia Selatan dan Timur ketika unit-unit politik telah mapan. Pandangan tersebut menjadi pijakan untuk menempatkan Asia Tenggara dalam proses perubahan sebagai implikasi jaringan maritim. Dalam konteks itu Zakharov menawarkan tesis, pertama bahwa organisasi politik di Asia Tenggara bukan negara primer, melainkan lebih pada jenis negara sekunder. Kedua, masyarakat Asia Tenggara telah dipengaruhi oleh kawasan dan masyarakat lain sepanjang sejarahnya, juga turut membentuk kawasan terdekat; ketiga, perlu memokuskan perhatian pada pembentukan negara di wilayah India karena satuan politik itu diungkapkan dalam bahasa Sanskerta atau juga bahasa beraksara India (Zakharov 2019, 219). Dengan ketiga tesis itu ia sependapat dengan proposisi bahwa negara-negara itu baru muncul paling lambat abad VII, sebagai titik balik dalam sejarah pembentukan negara-negara awal di Asia Tenggara (Wolters 1982). Alasan itulah yang mendorongnya untuk meninjau kembali rekonstruksi sejarah konvensional yang pernah digagas oleh Cœdès (1964).

Dua tesis pertama telah menjadi pengetahuan dasar akan peran agama dan perdagangan dalam proses difusi budaya; memicu kelahiran negara awal yang sangat dipengaruhi budaya India; dengan sebutan les Etats hindouisées (George Coedès 1964). Tertarik pada situs arkeologi di Teluk Jakarta, J.C. Nadine Dalsheimer dan Pierre-Yves Manguin menawarkan interpretasi baru terhadap arca Wisnu Cibuaya yang dikaitkan dengan religiusitas Tarumanagara. Dengan membandingkan ikonografis dan religiusitas dengan sejenisnya di Asia Tenggara dan di Asia Selatan, mereka mengusulkan bahwa penerbitan prasasti Sanskerta pada abad V bukanlah fase baru dalam pembentukan negara di koloni jauh. Oleh karena artefak itu mengandung unsur-unsur yang mendukung kedekatan kronologis, Patung Wisnu Cibuaya diyakini berasal dari paruh kedua abad V atau paling lambat awal abad VI (Dalsheimer dan Manguin 1998, 102).

Perspektif Wisnuisme itu diajukan untuk mengasosiasikan tipe kepercayaan dengan karakter khas penganutnya. Analogi dengan pengikut Budhisme yang memiliki peran dinamis dalam jaringan perdagangan di Teluk Benggala dan menolak konsep dasar penganut Brahmana yang secara ketat memegang prinsip kasta, memungkinkan penganut Budhis (agama misionaris) dapat bergerak melampaui batas-batas negara asal, bahkan pengaruhnya mencapai hampir seluruh Asia. Demikian pula dengan pengikut Wisnu, 
yang cenderung mengikuti jalur dakwah Buddhis, juga dapat menjangkau daerah luas, ke luar dari batasan kultural India. Berbekal doktrin universal bhakti mengizinkan penganut Wisnu untuk mencapai keselamatan dan mereduksi sistem kasta menjadi fakta sosial sehingga dalam perkembangannya, menurut Dalsheimer dan Manguin (1998, 110), para penganut Wisnu telah membentuk kekuatan integrasi dan asimilasi, dengan melakukan pengabdian bagi semua kalangan. Argumen itu memberi alasan untuk mengatakan bahwa sebagian sekte Wisnu di India hingga saat ini lebih terkait dengan lingkaran komersial.

Pengaruh sektarian ini ternyata menapak pada teritori Tarumanagara di Jawa Barat, maka tidak diragukan bahwa eksistensi kultural dari representasi Wisnu mencerminkan kaitan sinergis antara ekonomi dan politik. Keberadaan kelompok prasasti Sanskerta di sekitar Jakarta dan Bogor diasumsikan terasosiasi kuat dengan arca Wisnu di situs Cibuaya. Atas dasar itu pula, orientasi religius Tarumanagara dan penguasanya, Purnawarman, seperti ditegaskan kembali oleh Robert Wessing telah disepakati berbasis pada agama Hindu, yang dipresentasikan oleh penghormatan Wisnu dan Indra, selain juga untuk Siwa (Wessing 2011, 329).

Dalam kaitan itulah pertanyaan Robert Wessing, what's in a name menjadi relevan untuk memahami asal usul Tarumanagara. Didasarkan pada pendapat N.J. Krom yang menghubungkan kata tarumanegara dengan pohon indigo (Indigofera sp) (Krom 1931, 78), yang dalam bahasa Sunda disebut taru', bahan pewarna biru atau nila (Hermanus Johannes de Graaf 1949; Satjadibrata 1948, 35; taroem). Namun, menurut Robert Wessing (2011, 325), homonim itu agak mustahil digunakan untuk negara besar Tarumanagara. Oleh karena itu, ia mengembalikan toponim taruma pada tradisi India dari periode yang sama, yaitu merujuk pada nama Tarumapuram berdasarkan prasasti Cholapuram di Teluk Comorin, India selatan. Akan tetapi, jika mempertimbangkan pendapat Stutterheim bahwa tempat ini berasal dari abad XI, hal itu sependapat dengan Subbarayalu, asosiasi nama Tarumanagara dengan Tarumapuram menjadi tidak relevan (Stutterheim 1939, 82; Wessing 2011, 325--26).

Berbeda halnya dengan J.L. Moens, dengan mempertimbangkan perluasan budaya, toponim sakral lazim digunakan untuk menamai lokasi baru, sejenis negara bagian dari pusatnya di India (Moens 1940, 79--109). Mengaitkan kemunculan namanama tempat kuna dan dua saluran air dalam prasasti Purnawarman dan dibandingkan dengan sejenisnya di India dan Ceylon, Wheatley menyimpulkan bahwa nama Taruma boleh jadi diadopsi dari tempat asalnya dan mungkin berpengaruh pada toponim lokal (tarum). Atas dasar itulah Wessing tidak menampik jika penggunaan toponim sakral menjadi lumrah untuk menamai tempat baru yang diasumsikan sebagai wilayah koloni India (Wheatley 1983; Wessing 2011).

Argumentasi di atas menjelaskan bahwa Tarumanagara bukan sekadar nama, melainkan memiliki arti sejauh yang dapat dikupas dari kesaksian tertulis. Dengan mempertimbangkan lokasinya sebagai indikator penting, Tarumanagara mencakup wilayah sebagian besar Jawa bagian barat dan satu di antaranya berada jauh di pedalaman selatan Banten. Maka, beralasan apabila studi Tarumanagara dikaitkan dengan keberadaan unit kekuasaan yang pernah memerintah. Dengan sedikit mengabaikan 
perbedaan pandangan tentang konsep negara, perspektif politik berguna dalam memahami keberadaan sebuah unit kekuasaan sebagai city-state atau juga port-polity (Manguin 2000; Kathirithamby-Wells dan Villiers 1990). Bahwa keberadaan prasastiprasasti Mulawarman dan Purnawarman adalah referensi menuju definisi kota dan negara bagian dalam proses perkembangannya karenanya Prasasti Mulawarman dan Purnawarman menggambarkan transformasi kekuasaan politik pada sekitar abad IV dan $\mathrm{V}$, sebagai awal pembentukan kerajaan bagi periode selanjutnya, seperti yang dicontohkan oleh prasasti-prasasti Sriwijaya awal serta Jawa Tengah dan Timur dari akhir abad VII hingga XII. Simpulannya adalah fase awal negara merupakan transisi dari kekuasaan lokal ke kerajaan besar, sebagaimana digambarkan dengan sangat instruktif dalam prasasti Mulawarman pada abad IV. Tujuh prasasti yupa atau tiang batu kurban yang mirip menhir mengandung keunikan kisah kebangkitan seorang pemimpin lokal dan transformasinya menjadi kerajaan awal dalam tiga generasi (Kulke 1989).

Berbeda dengan kasus di Kutai, menurut Kulke, Prasasti Purnawarman mengungkapkan gambaran awal suatu negara yang sedikit lebih berkembang. Purnawarman dipuji sebagai "Tuan di negeri Taruma" dengan gelar kebesaran Rajadhiraja. Jika pendahulunya telah menggali kanal yang melintas kota (puri), Purnawarman menggali kanal lain yang lebih luas. Prasasti Purnawarman juga menyebutkan tiga generasi, yang sejak masa sebelumnya sudah mampu menetapkan otoritasnya kepada penguasa lain dan kebijakan itu dilanjutkan sebagaimana secara eksplisit dipuji dalam Prasasti Jambu (Pasir Koleangkak) sebagai penakluk musuhmusuhnya. Dengan demikian Purnawarman tidak diragukan sebagai penguasa yang telah mencapai era keemasan Tarumanagara (Noorduyn dan Verstappen 1972, 398--470).

Berkenaan dengan toponim Taruma beberapa sarjana masih silang pendapat. Kulke memberi jalan dengan mulai dari konsep negara pada periode awal itu. Penjelasan didasarkan pada penggunaan istilah nagara pada empat prasasti. Pertama, Prasasti Ciaruteun yang memuji Purnawarman sebagai Penguasa Tarumanagara (tarumanagarendrasya), kedua adalah Prasasti Jambu yang menyebut arinagara sebagai negeri taklukan. Sementara itu, prasasti Kebon Kopi juga menyatakan pujian pada Penguasa (di) Taruma, tetapi tanpa menyebut nagara (tarumendrasya) dan prasasti Tugu sangat menarik dengan menyebut dua kanal dan istilah sibira-vanim. Jika sibira diasosiasikan dengan tempat yang dibentengi, berkorelasi kuat dengan keberadaan taruma sebagai kota, yang sekaligus juga menjadi nama nagara. Hipotesis Kulke dapat dilihat pada pernyataan berikut.

"The meager epigraphical evidence does not allow a clear distinction between these three terms. But we may infer that sibira meant a fortified place, perhaps the kraton of Purnavarman or his grandfather, which was situated within the pun. This expression then would refer to Taruma as a semi-urban or urban-like settlement" (Kulke 1989: 6).

Selanjutnya, dikatakan bahwa istilah nagara merujuk pada kota dan pedalaman yang dikuasai. Namun, diakui bahwa hal itu tetap menjadi masalah ketika dihadapkan 
pada pertanyaan apakah prasasti membedakan antara keraton, kota, dan pedalaman yang secara politik dikendalikan dari pemerintah pusat. Sehubungan dengan itu, penting menimbang fakta bahwa hanya istilah nagara yang muncul dalam kaitan dengan Taruma dan pemerintahan musuh yang dikalahkannya sebagai konsep spasial dan kota yang terpusat (city-centerd); menegaskan definisi Wheatley tentang unit-unit politik awal di Semenanjung Malaya, yang menurut sumber-sumber Cina bahwa nagara adalah sebuah pemerintahan pada permukiman terpusat yang memegang kendali atas daerah pinggiran dari mana upeti berasal (Wheatley, 1983, 233; Kulke 1989, 7).

Jika perbandingan ini dapat diterima, prasasti Cidanghyang yang berada di luar jangkauan pusat mengindikasikan daerah taklukan atau meminjam istilah Kulke sebagai restricted peripheral territory. Kendati tidak menyebutkan arinagara, tetapi prasasti itu memuat klaim kekuasaan seperti pesannya, "Inilah (tanda) keperwiraan, keagungan, dan keberanian yang sesungguhnya dari raja dunia, yang mulia Purnawarman, yang menjadi panji sekalian raja”. Sebuah analogi perlu disampaikan, adanya pengaruh India pada toponim kuna cidanghyang — diambil dari kata danghyang yang dalam bahasa Sunda diartikan 'penguasa gaib' - mengalir ke Ci Liman. Istilah ini merupakan bentukan dari kata ci (Sunda: 'air') dan liman yang dalam Bahasa Jawa Kuna identik dengan 'gajah' (Zoetmulder 2006). Gajah dinyatakan pada Prasasti Kebon Kopi, tidak jauh dari prasasti Ciaruteun, yang menggambarkan telapak kaki Airawati, untuk menyebut gajah yang kuat (airwaytabhasya vibatidam).

Jika mengacu pada ulasan di atas, dapat dirumuskan bahwa nilai penting Prasasti Cidahyang didasarkan fakta arkeologi dan sejarah. Pertama, dari sisi bahasa dan sastra, keberadaan prasasti sangat penting bagi pengayaan literasi tentang asal usul dan perkembangan bahasa Sanskerta dan seni kaligrafi yang terukir di atas batu (Griffiths, 2014). Kedua, dari sisi muatan (content), prasasti itu penting sebagai bukti keberadaan kerajaan Tarumanagara, yang tidak hanya berada di sekitar Jakarta, Bekasi, Bogor, dan Karawang, tetapi juga wilayah teriotorialnya sampai ke Selatan Sunda. Dengan demikian, Prasasti Cidanghyang merupakan bukti keberadaan kerajaan awal bercorak Hindu pada abad V sebelum dilanjutkan oleh kekuasaan Sriwijaya, Majapahit, Sunda dan Kesultanan Banten. Ketiga, dari dimensi waktu, Prasasti Cidanghyang dan Tarumanagara lainnya menjadi patokan awal masuknya Indonesia ke dalam periode sejarah, yang ditandai dengan dikenalnya tulisan.

Narasi sejarah tersebut juga penting diketahui oleh masyarakat di Banten selatan bahwa tonggak awal sejarah itu berada di lingkungan desanya yang terpencil, jauh dari peradaban modern yang berpusat di ibu kota provinsi dan kabupaten. Pengetahuan sejarah dan arkeologi tersebut menjadi dasar untuk memandang betapa mendesaknya upaya penyelamatan, pelestarian, dan pengembangan informasi bagi peningkatan pengetahuan masyarakat dan media pendidikan luar sekolah. Maka, mengidentifikasi tingkat ancaman sedini mungkin merupakan tindakan awal dari perencanaan mitigasi bencana, baik yang disebabkan oleh alam maupun sosial di situs Prasasti Cidanghyang. 


\section{Ke Arah Upaya Mitigasi}

Pada awal bulan Oktober 2020 kondisi prasasti, situs dan lingkungannya masih tampak aman dari ancaman banjir. Muka air Ciliman dalam posisi bergerak naik dengan kecepatan arus sedang dan berwarna kecoklatan, menandai kandungan lumpur, mengalir ke muara di daerah Panimbang (Selat Sunda). Untuk mencapai lokasi, ditempuh jalur dari Munjul ke arah Panimbang, kemudian dilanjutkan ke selatan menuju Desa Lebak sejauh $3,80 \mathrm{~km}$. Kondisi jalan sebagian sudah baik (cor beton), tetapi setelah $2 \mathrm{~km}$ menuju lokasi kondisi jalan sudah rusak dan sebagian lagi masih berbatu. Beberapa ruas jalan tergenang air, terutama di daerah persawahan sepanjang tanggul sungai. Dari Balai Desa menuju situs tersedia jalan yang dapat dilalui kendaraan roda 4 sampai di depan situs (Gambar $3)$.

Akses masuk ke situs cukup lebar yang dapat dimanfaatkan penduduk untuk mengangkut hasil kebun. Sepanjang jalan terdapat tanaman keras: mahoni, kelapa, albasiah, bambu, dan beberapa pohon kelapa sawit. Untuk memasuki situs ditempuh berjalan kaki melewati jembatan di atas sodetan sungai. Keadaan situs sangat baik dan terawat serta dirancang menyerupai taman yang terlindung dari sengatan matahari oleh pepohonan besar, seperti mahoni, rengas, dan pohon keras lainnya pada tanah darat sekitar meander sungai. Dengan kelembapan sedang, situs cukup ideal untuk beristirahat. Luas situs sekitar 4 ha dihitung dari prasasti sebagai patokan. Sebagian besar lahan menjadi garapan masyarakat dengan aktivitas utama berkebun. Di sebelah timur terdapat perbukitan cukup terjal, menyediakan sumber air langsung ke aliran Ci Danghyang.

Prasasti Cidanghiang masih in situ dalam wilayah Desa Lebak di bawah pengelolaan langsung Balai Pelestarian Cagar Budaya (BPCB) Banten. Keberadaan prasasti pertama kali dipublikasikan oleh Dinas Purbakala atas laporan penemuan Toebagoes Roesjan pada tahun 1947. Pada tahun 1954 ahli epigrafi dari Dinas Purbakala datang ke lokasi untuk membuat transkripsi dan alih bahasa (Simanjuntak 2007, 61). Prasasti Cidanghyang terkadang juga disebut Prasasti Munjul, dipahatkan pada bidang atas batu andesit 3 × 2 × 2 meter, dalam 2 baris aksara Pallawa berbahasa Sansekerta, dan dengan metrum Anustubh (Damais 1967, 685--94).

Beberapa bentuk huruf menunjukkan kemiripan dengan pahatan Prasasti Tugu. Saat ini aksara prasasti masih cukup jelas terbaca walaupun beberapa sudah menampakkan keausan. Bagian atas sebelah kanan batu prasasti sudah patah. Hasil pengamatan dan mengacu pada laporan pekerjaan teknis BPCB yang dikuatkan dengan komunikasi personal dengan juru pelihara situs, memberikan informasi singkat tentang pekerjaan teknis (Safiudin 1993; Tim BPCB 2020; Balai Pelestarian Cagar Budaya Provinsi Banten 2015).

Secara kronologis pekerjaan konservasi telah dilakukan sejak tahun 1985, artinya situs ini baru mendapat perhatian setelah tiga puluhan tahun sejak laporan penemuan, waktu yang cukup berisiko degradasi fisik. Pekerjaan fisik yang berkaitan langsung dengan konservasi sudah dimulai pada tahun 1985 berupa pembuatan sodetan (terusan) dengan memotong bagian pangkal meander yang menyempit di bagian hulu. Kemudian, pada tahun 1993 pembuatan fondasi dari pasangan batu belah berplester setinggi 60 meter 
dari dasar sungai, mengelilingi batu prasasti untuk menghindari terjangan langsung aliran air terhadap objek.

Pada tahun yang sama, pembuatan turap pada dinding sungai yang dekat dengan objek, dimaksudkan untuk mencegah longsoran tanah yang mengarah ke batu prasasti, sedangkan fasilitas pendukung pada tahun itu juga dibuatkan bangunan cungkup berukuran $4 \times 4 \mathrm{~m}$ dengan bangunan tanpa dinding agar objek terlindung dari sinar matahari dan juga hujan. Bangunan cungkup itu, selain dapat menghambat proses pelapukan, juga dapat menghindari kerusakan fatal apabila beberapa pohon besar di sekitarnya roboh menimpa batu prasasti (Gambar 4).

Pekerjaan itu belum cukup aman untuk melindungi prasasti dari luapan air sungai karena pada musim penghujan tinggi air dapat mencapai dua meter dari dasar sungai, dengan arus yang sangat kuat. Mitigasi terhadap ancaman itu baru dilakukan setelah berlangsung empat tahun, dengan melakukan dua pekerjaan bersamaan, yaitu memperdalam dan memperlebar dinding sodetan (Gambar 5) dan juga membangun semacam bendung bronjong dari susunan batu belah pada pangkal meander (Gambar 6). Pekerjaan itu ditujukan untuk mengalihkan aliran sungai agar tidak memasuki areal batu prasasti. Sodetan yang dikerjakan pada tahun 1997 kenyataannya belum efektif karena lebar sodetan tidak cukup besar untuk pengalihan arus sehingga pada puncak musim hujan, dinding sodetan mengalami abrasi dan mengakibatkan runtuhnya fondasi jembatan yang terbuat dari beton cor. Dampaknya adalah luapan air sungai juga masih dapat memasuki meander yang langsung melewati batu prasasti.

Masalah tersebut baru mendapat solusi pada tahun 2017, artinya harus menunggu selama dua puluh tahun untuk menyelesaikan masalah. Pekerjaan pertama adalah meninggikan bendung agar muka air stabil pada musim penghujan dan pekerjaan kedua adalah memperdalam dan menambah lebar sodetan agar air sungai dapat mengalir deras tanpa memasuki aliran menuju prasasti (Gambar 7). Pada tahun itu juga dilakukan tiga pekerjaan simultan yang dilakukan oleh Pemerintah Kabupaten Pandeglang melalui Dinas Pendidikan dan Kebudayaan, yaitu penambahan dinding di atas fondasi setinggi $1,70 \mathrm{~cm}$, pembuatan pagar besi (teralis) sekeliling prasasti, dan pemasangan lantai keramik seluas $4 \times 4 \mathrm{~m}$, yang hanya menyisakan batu prasasti di bagian tengah.

Pada tahun 2018 dilakukan pemutakhiran mitigasi dengan meninggikan bendung yang mencapai $1,75 \mathrm{~m}$ dari dasar sungai, dengan panjang $25 \mathrm{~m}$ dan lebar 1,50 m. Pekerjaan itu dilakukan oleh Dinas Pekerjaan Umum dan Perumahan Rakyat Provinsi Banten. Pengamatan di lapangan menunjukkan bahwa tingkat keamanan prasasti dapat diukur dari debit air yang masuk melalui celah bronjong. Bendungan itu sangat efektif untuk dua hal, yaitu aliran sungai menuju prasasti tidak sama sekali kering, tetapi mengalir perlahan dan lancar, sementara pada musim penghujan air sungai mengalir deras melalui sodetan. Untuk memudahkan akses ke lokasi prasasti, di atas sodetan, setelah jembatan beton rusak akibat erosi kedua dindingnya, pada tahun 2018 telah dibangun jembatan yang terbuat dari logam oleh BPCB Banten sekitar panjang 7 meter dengan lebar 1,5 m, cukup memberi ruang dan kenyamanan bagi pengunjung untuk memasuki zona inti. 
Dari perspektif CRM dan DRM, efektivitas ketiga jenis pekerjaan itu tampaknya memerlukan pengkajian ulang, yaitu

1. Meninggikan fondasi dengan dinding tinggi tidak lagi relevan untuk mencegah luapan sungai karena bendungan telah mengubah aliran menjadi stabil. Sebaliknya, dinding membatasi ruang pandang sehingga dari segi utilitas dan estika (visual disturbance) tidak merujuk pada konsep archaeological park. Dalam konsep CRM, inefficiency mestinya tidak boleh terjadi;

2. Membuat pagar besi, jika dimaksudkan untuk melindungi prasasti dari vandalisme, tidak efektif karena penetrasi dari bagian atas pagar dimungkinkan. Sebaliknya, pagar teralis mempersempit ruang inti prasasti, memungkinkan pengunjung berkerumun over-capacity dan terlalu dekat dengan prasasti (Gambar 8). Ketiadaan jarak ideal antara pengunjung dan objek memberi peluang menginjak atau menduduki objek semena-mena. Vandalisme dengan demikian cenderung dimudahkan, seperti ditemukan guratan pada bidang tulis prasasti dengan menggunakan benda logam sedalam 1-2 mm. Pada replika prasasti yang dibuat oleh Museum Negeri Provinsi Banten untuk koleksi pameran tetapnya, tulisan itu masih jelas terlihat;

3. Memasang keramik mengesankan sebuah 'makam keramat' yang menyediakan ruang bagi pengunjung melakukan unrecomended activity, seperti duduk, berdiri, dan mengerumuni objek, yang tidak mustahil membakar dupa dan melumurinya dengan sejenis minyak. Hal itu tidak selaras dengan tujuan pelestarian karena mengurangi makna kekunoan prasasti. Berbeda sekali dengan situs sejenis, sekeliling Prasasti Jambu dan Kebon Kopi misalnya, dibuatkan lantai dari pasangan batu monolit; menunjukkan kepantasan alami;

4. Mengerjakan sodetan masih terkesan sebagai tindakan pengamanan sementara untuk sekadar mengalihkan arus. Jika melihat lebar celah dan tingginya kedua dinding sodeten, tampaknya pekerjaan itu belum didasarkan peningkatan volume air, kecepatan, dan tekanan maksimum arus sungai saat musim penghujan. Mengingat gejala intensifikasi dan ekstensifikasi aktivitas pertanian dan perkebunan di sekitar perbukitan dan bagian hulu sungai, ancaman longsor dan air bah masih berpotensi merusak situs. Maka, kondisi saat ini belum memberi jaminan perlindungan yang berjangka panjang bagi prasasti beserta situs dan lingkungannya.

\section{SIMPULAN}

Tujuan utama pemilihan topik adalah untuk mengungkapkan makna subjektif warisan budaya. Secara teoretis situs prasasti Cidanghyang merupakan subjek potensial berbagai kajian disiplin ilmu di luar arkeologi. Relevansinya dengan masa sekarang terletak pada korelasi antara material arkeologi dengan makna saintifik. Secara pragmatis, prasasti merupakan media potensial pembelajaran nonkelas yang berdampak pada integritas sosial. Sebagai material arkeologi, situs itu merupakan target unik visitasi publik dalam pemenuhan kebutuhan edukatif luar sekolah. Maka, argumen teoretis dan pragmatis menempatkan prasasti relevan untuk mendapat perhatian khusus. 
Mengingat relasi kuat antara fakta arkeologi dan fungsi ideografis, penting untuk mengangkat isu pelestarian dalam format mitigasi sebagai dasar rasional bagi upaya pencegahan potensi ancaman alamiah dan sosial. Langkah-langkah manajemen yang perlu diusulkan dimulai dari isu strategis atas fakta-fakta di lapangan dan menemukan pendekatan sistemik untuk membangun sebuah CRM model sekaligus juga penerapan DRM pada situs prasasti Cidanghyang yang diharapkan menjadi praktik baik (best practice) dalam pengelolaan cagar budaya peringkat nasional.

Langkah pertama dapat dimulai dengan penetapan aspek legal antarpemangku kepentingan, mencakup perencanaan dan sumber pembiayaan bagi pengelolaan situs. Setelah itu, penyiapan konsep aplikatif bagi penguatan komunikasi sinambung melalui sosialisasi muatan kognitif dan normatif tentang cagar budaya. Muatan kognitif yang dimaksud di sini adalah suatu proses perubahan dalam pemahaman dan persepsi yang dilandasi oleh pengetahuan tentang sejarah dan kebudayaan dari hasil penelitian dan pelestarian cagar budaya, sedangkan muatan normatif adalah pengalaman individual yang diperoleh dari kujungan ke situs prasasti yang berdampak pada pembentukan kepribadian berdasarkan norma-norma kehidupan individual dan sosial, sebagai warga negara Indonesia sekaligus juga warga dunia.

Langkah berikutnya adalah menetapkan rencana berkala untuk pelatihan terspesialisasi yang dibutuhkan untuk mendukung kinerja konservasi, restorasi, pengelolaan, dan pemanfaatan cagar budaya secara sinergis dan berkesinambungan (Alexander 1990, 280--84). Terakhir, menyiapkan sistem manajemen terpadu lengkap dengan peta jalan yang mencakup seluruh aktivitas pengelolaan, pemanfaatan, dan mitigasi sumber daya arkeologi yang memungkinkan direplikasikan pada situs lain di Provinsi Banten.

\section{Ucapan Terima kasih}

Ucapan terima kasih disampaikan kepada Drs. Sarif Akhmadi, M.Hum., Juliadi, S.S., M.Si., Dadan Sujana, M.Pd, Samsu Bahri, S. Pd., STKIP Setiabudhi Rangkasbitung, Sdr. Alam Sukmajaya, Sdr. Memed (Jupel Situs Prasasti Cidanghyang) dan Sdri. Tasmen, mahasiswa Jurusan Pendidikan Sejarah, FKIP Untirta yang telah membantu dalam survei lapangan.

\section{DAFTAR PUSTAKA}

Alexander, John. 1990. "A Suggested training scheme for archaeological resource managers in tropical countries." In Archaeological Heritage Management in the Modern World, diedit oleh H.F. Cleere, 280-84. London: Unwin Hyman Ltd.

Alisjahbana, Armida Salsiah., Murniningtyas, Endah. 2018. Tujuan Pembangunan Berkelanjutan: Konsep, Target dan Strategi Implementasi,. Bandung: Unpad Press.

Balai Pelestarian Cagar Budaya Provinsi Banten. 2015. "Laporan Studi Penanganan Situs Prasasti Munjul, Kabupaten Pandeglang, Provinsi Banten.” Serang.

BPCB Team. 2020. "Laporan Pengembangan Atribut Jalur Rempah Simpul Banten.” 
Serang, Banten.

Chandra, Dodi. 2018. "Mitigasi Bencana dalam Konteks Pelestarian Cagar Budaya." Indonesiana Flatform Kebudayaan. 2018.

Chhabra, B. Ch. 1965. Expansion of Indo-Aryan Culture during the Pällava Rule (as evidenced by inscriptions). Delhi: Munshi Ram Manohar Lal.

Cleere, Henry. 1990. Archaeological Heritage Management in the Modern World. London: Routledge-Unwin Hyman.

Coedès, G. 1964. Les Etats hindouisés d'Indochine et d'Indonésie. Paris: Editions Boccard.

Coedès, George. 1964. Les Etats hindouisés d'Indochine et d'Indonésie. Paris: Editions Boccard.

Dalsheimer, J.-C. Nadine, dan Pierre- Yves Manguin. 1998. "Visnu mitres et réseaux marchands en Asie du Sud-Est nouvelles données archéologiques sur le Ier millénaire apr. J.-C.” BEFEO 85: 87-112.

Damais, Louis-Charles. 1967. "Une publication récente du Service archéologique de 1'Indonésie. Dinas Purbakala. Departmen P.P. dan K. Laporan Tahunan 1954.” BEFEO 53: 685-94.

Glover, I. C., dan P. (eds.) Bellwood. 2004. Southeast Asia: From Prehistory to History. London: Routledge Curzon.

Griffiths, Arlo. 2014. "Early Indic Inscriptions of Southeast Asia." In Lost Kingdoms Hindu-Buddhist Sculpture of Early Southeast Asia, 53-57. New York: The Metropolitan Museum of Art.

Guillot, Claude. 1995. “Archéologie et Indépendence.” In Perspectives Indonésiennes, 24-29. Paris: L'Ambassade de la République d'Indonésie en France.

Hermanus Johannes de Graaf. 1949. Geschiedenis van Indonesie. 's Gravenhage Bandung: Martinus Nijhoff.

Kangas, Anita., Duxbury, Nancy., Beukela, Cristian de. 2017. "Introduction: Cultural Policies for Sustainable Development, International Journal of Cultural Policy." International Journal of Cultural Policy 23 (2): 129-132.

Kathirithamby-Wells, J., dan J. (eds.) Villiers. 1990. The Southeast Asian Port and Polity: Rise and Demise. Singapore: Singapore University Press.

Kristiansen, Kristian. 1990. "Perspectives on the Archaeological Heritage, History and Future." In Archaeological Heritage Management in the Modern World, diedit oleh H.F. Cleere, 23-26. London: Unwin Hyman Ltd.

Kristofery, Leonard.. Murtilaksono, Kukuh., Baskoro, Dwi Putro Tejo. 2019. "Simulasi Perubahan Penggunaan Lahan Terhadap Karakteristik Hidrologi Daerah Aliran Sungai Ciliman." Jurnal Ilmu Tanah dan Lingkungan 21 (2): 66-71. https://doi.org/10.29244/jitl.21.2.66-71.

Krom, Nicolaas Joannes. 1931. Hindoe-Javaansche GeschiedenisNo Title. 'sGravenhage: Martinus Nijhoff.

Kulke, Hermann. 1989. "Epigraphical References to the City and the State in Early 
Indonesia." In Panel on early Indonesian state formation during the Association for Asian Studies Meeting. Washington DC.

Lubis, Saut M. 2000. Indikator Pembangunan Berkelanjutan: Upaya Mencapai Kehidupan Yang Makin Berkualitas. Jakarta: Proyek Agenda 21 Sektoral.

Manguin, Pierre-Yves. 2000. "Les cités-États de l'Asie du Sud-Est côtière: De l'ancienneté et de la permanence des formes urbaines." In Bulletin de l'Ecole française d'Extrême-Orient, 87:151-82. Paris: https://doi.org/10.3406/befeo.2000.3474.

- 2002. "The Amorphous Nature of Coastal Polities in Insular Southeast Asia: Restricted Centres, Extended Peripheries." Moussons 5: 73-99.

Moens, J.L. 1940. "Was Pūrnavarman van Taruma een Saura?” Tijdschrift voor Indische Taal-, Land- en Volkenkunde 80: 78-109.

Moleong, Lexy J. 2005. Metodologi Penelitian Kualitatif. Bandung: PT Remaja Rosdakarya.

Noorduyn, J., dan H. Th. Verstappen. 1972. "Pūrnavarman's river-works near Tugu." Bijdragen tot de Taal-, Land-en Volkenkunde 128 (1/3): 298-307.

Poirier, D. A., dan L. F. Kenneth. 1995. "Sharing the past with the present." CRM, Archaeology and the Public 18 (3): 3-4.

Rahmani, Dienny Redha, dan Hanny Maria Caesarina. 2020. "Studi Keterpenuhan Tutupan Hijau Kawasan Wisata Makam Sultan Suriansyah di Tepian Sungai Kuin Banjarmasin." Science, Technology and Agriculture Journal 1 (2): 67-70.

Rieth, Christina B. 2007. "Public Archaeology and Education in Research and Compliance Projects: An Introduction." Northeast Anthropology 73: 1-11.

Safiudin. 1993. "Laporan Hasil Kegiatan, Pekerjaan Penyodetan Sungai dan Pembuatan Jembatan Penyeberangan ke Situs Batu Tulis Cidanghyang, Desa Lebak, Kec. Munjul, Kab. Pandeglang, Jawa Barat.” Serang.

Satjadibrata, R. 1948. Kamoes Basa Sunda. Jakarta: Balai Pustaka.

Simanjuntak, Truman (ed). 2007. Archaeological Discovery in Indonesia (1950-1980). Jakarta: The National Research and Development Centre of Archaeology of Indonesia.

Solihuddin, Tubagus., Prihantono, Joko., Mustikasar, Eva., Husrin, Semeidi. 2020. "Dinamika Perubahan Garis Pantai di Perairan Banten dan Sekitarnya." Jurnal Geologi Kelautan 18 (2): 73-85.

Stutterheim, Willem Frederik. 1939. "Note on the cultural relations between South-India and Java'." Tijdschrift voor Indische Taal-, Land-en Volkenkunde 39.

Sulistyanto, Bambang. 2009. "Penerapan Cultural Resource Management dalam Arkeologi." Amerta, Jurnal Penelitian dan Pengembangan Arkeologi 27 (1): 1630 .

Supratikno Rahardjo, Tawalinuddin Haris, Kresno Yulianto, Inggrid H.E. Pojoh. 2011. Kota Banten Lama Mengelola Warisan untuk Masa Depan. Jakarta: Wedatama Widya Sastra. 
Trotzig, Gustaf. 1990. "The Cultural dimension of development, an archaeological approach." In Archaeological Heritage Management in the Modern World, diedit oleh H.F. Cleere, 59-62. London: Unwin Hyman Ltd.

Vogel, Jean Ph. 1925. "The earliest Sanskrit inscriptions of Java." Publicaties van den Oudheidkundigen Dienst in Nederlandsch-Indië - 1, Koninklijk Bataviaasch Genootschap van Kunsten en Wetenschappen, 1925.

Wessing, Robert. 2011. “Tarumanagara: What's in a name?" Journal of Southeast Asian Studies 42 (2): 325-337.

Wheatley, Paul. 1983. Nagara and Commandery: Origins of the Southeast Asian Urban Traditions. Chicago: University of Chicago.

Wolters, O. W. 1982. History, Culture, and Region in Southeast Asian Perspectives. Singapore: Institute of Southeast Asian Studies.

Yogaswara, Herry, dan Tine Suartina. 2014. Banten Lama dalam Perkembangan: Politik Ekonomi Pengelolaan Cagar Budaya. Jakarta: LIPI.

Zahorka, Herwig. 2007. The Sunda Kingdoms of West Java: From Tarumanagara to Pakuan Pajajaran with the Royal Cnter of Bogor. Jakarta: Yayasan Cipta Loka Caraka.

Zakharov, Anton O. 2019. "State Formation in First Millennium Southeast Asia: A Reappraisal." Social Evolution \& History 18 (1): 217-240.

Zoetmulder, Petrus Josephus. 2006. Kamus Jawa Kuna - Indonesia. Jakarta: Gramedia Pustaka Utama. 


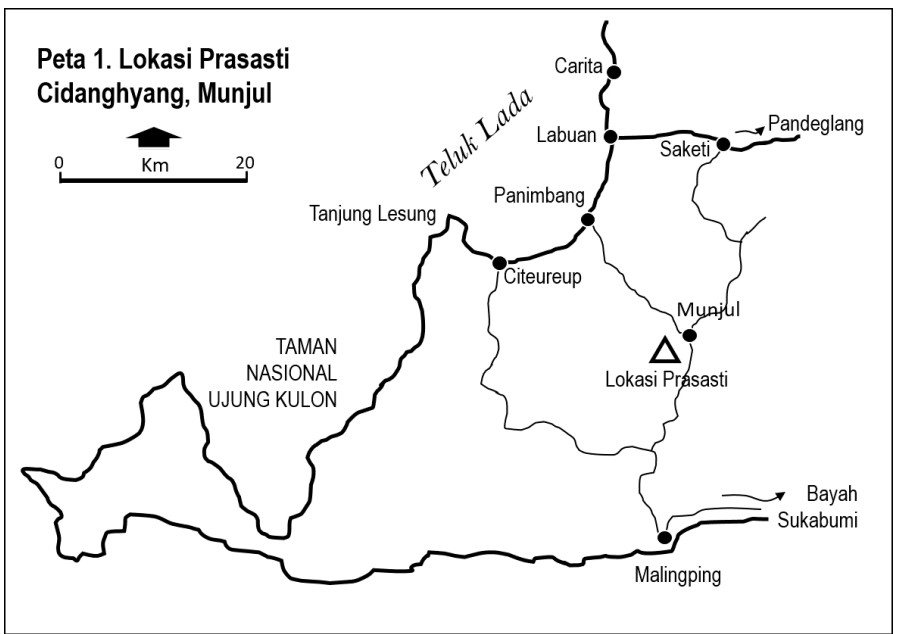

Gambar 1. Lokasi Prasasti Cidanghyang di Hulu Ci Liman, Dekat Munjul, Pandeglang, Banten (Sumber: Balai Pelestarian Cagar Budaya Banten, 2015 dengan Modifikasi).

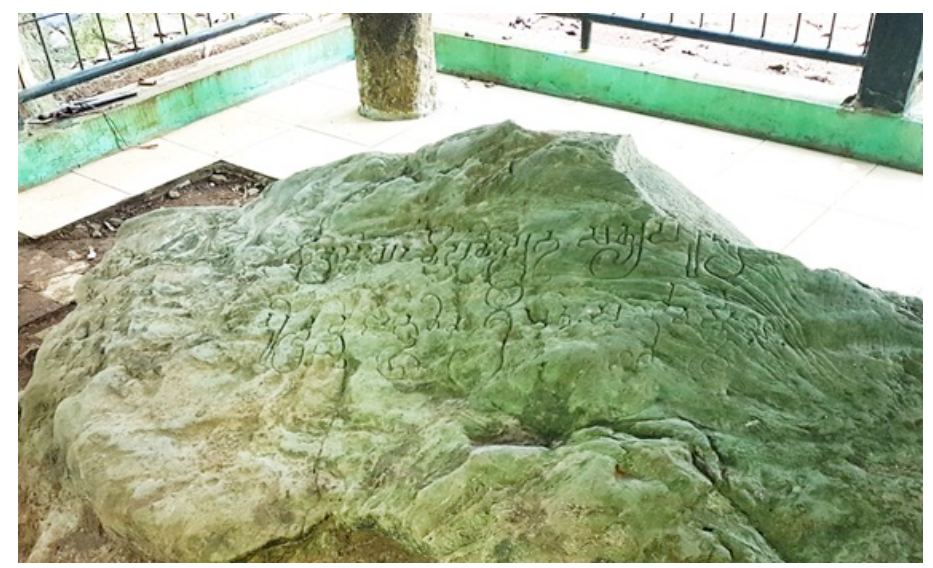

Gambar 2. Prasasti Batu Purnawarman di Ci Danghyang, Munjul, Pandeglang (Sumber: Dokumen Mohammad Ali Fadillah, 2020). 


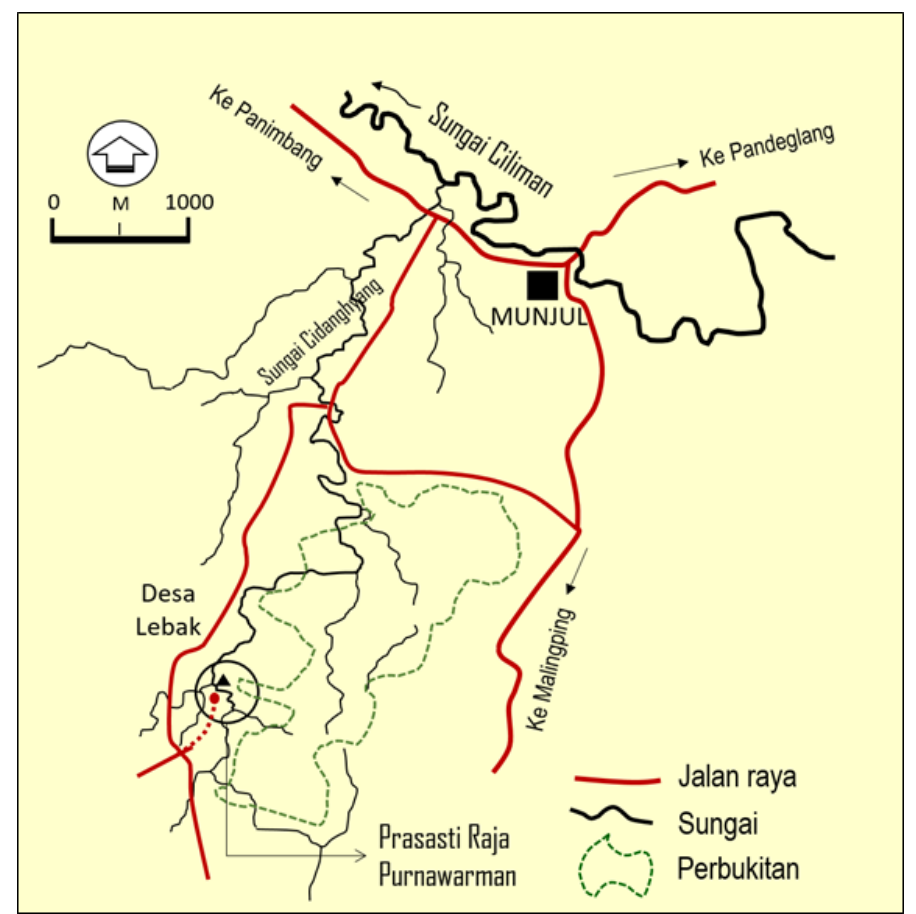

Gambar 3. Posisi Prasasti Cidanghyang dalam Jaringan Hulu Ci Liman (Sumber: Peta Suaka Peninggalan Sejarah dan Purbakala Serang, 1993 dengan Modifikasi).

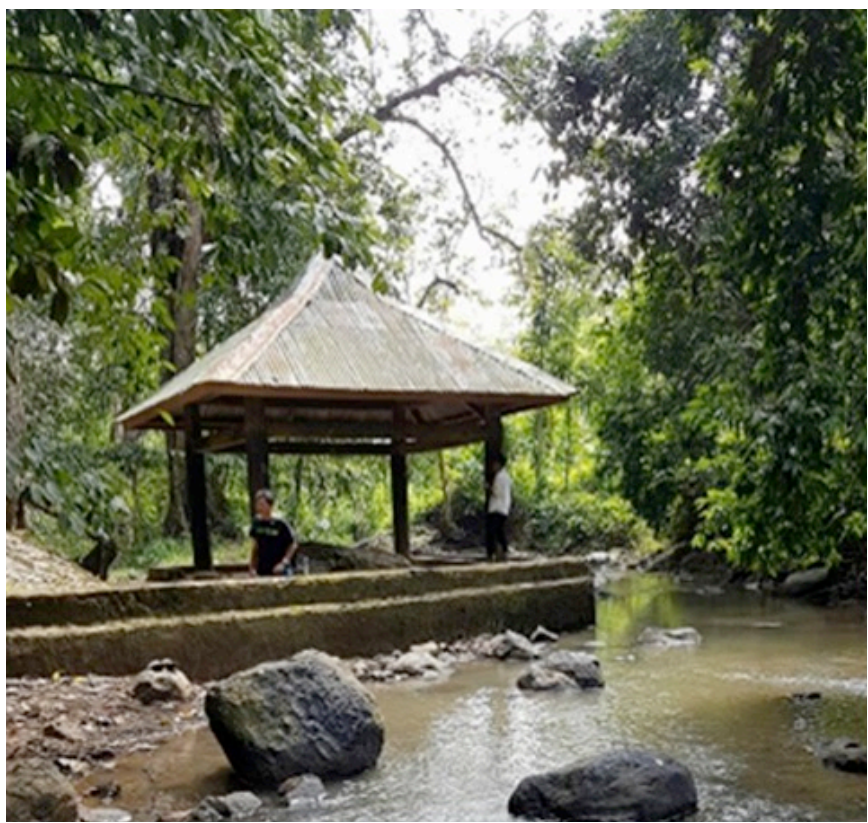

Gambar 4. Letak Prasasti Purnawarman di Aliran Ci Danghyang (Sumber: Dokumen Mohammad Ali Fadillah, 2017). 
PURBAWIDYA: $\square$ Vol 10, No. 1, Juni 2021: 63-86

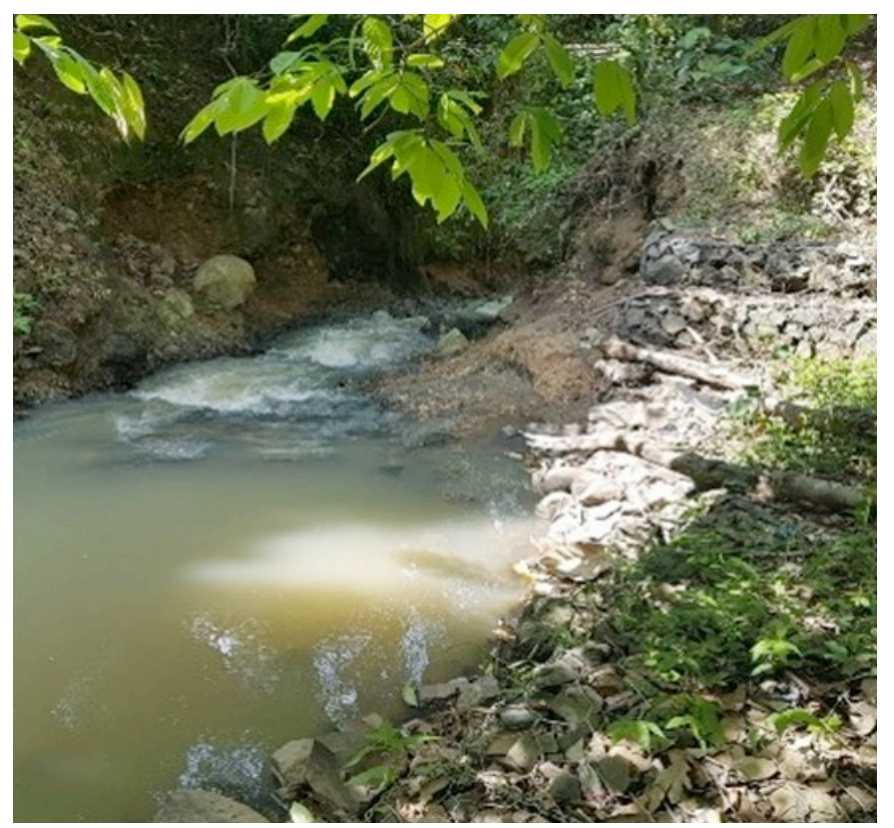

Gambar 5. Sodetan Memotong Aliran Ci Danghyang (Sumber: Dokumen Mohammad Ali Fadillah, 2020).

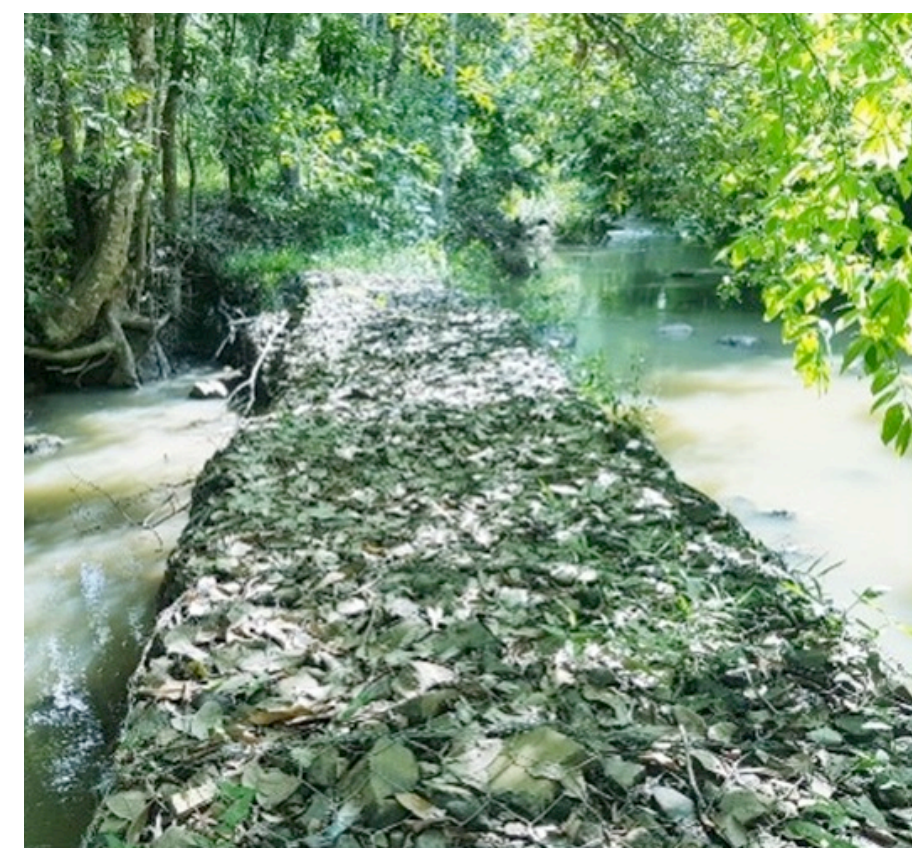

Gambar 6. Bendung - bronjong di aliran Ci Danghyang (Sumber: Dokumen Mohammad Ali Fadillah, 2020). 


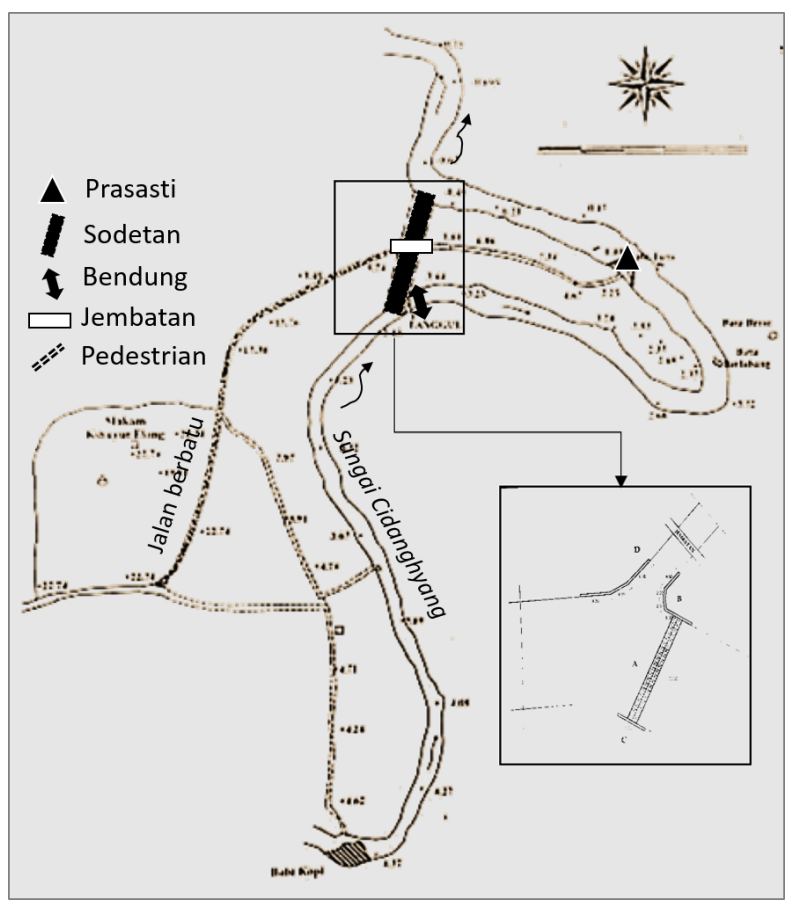

Gambar 7. Sodetan dan Bendung di Sekitar Lokasi Prasasti Cidanghyang (Sumber: Dokumen Suaka Peninggalan Sejarah dan Purbakala Serang, 1993).

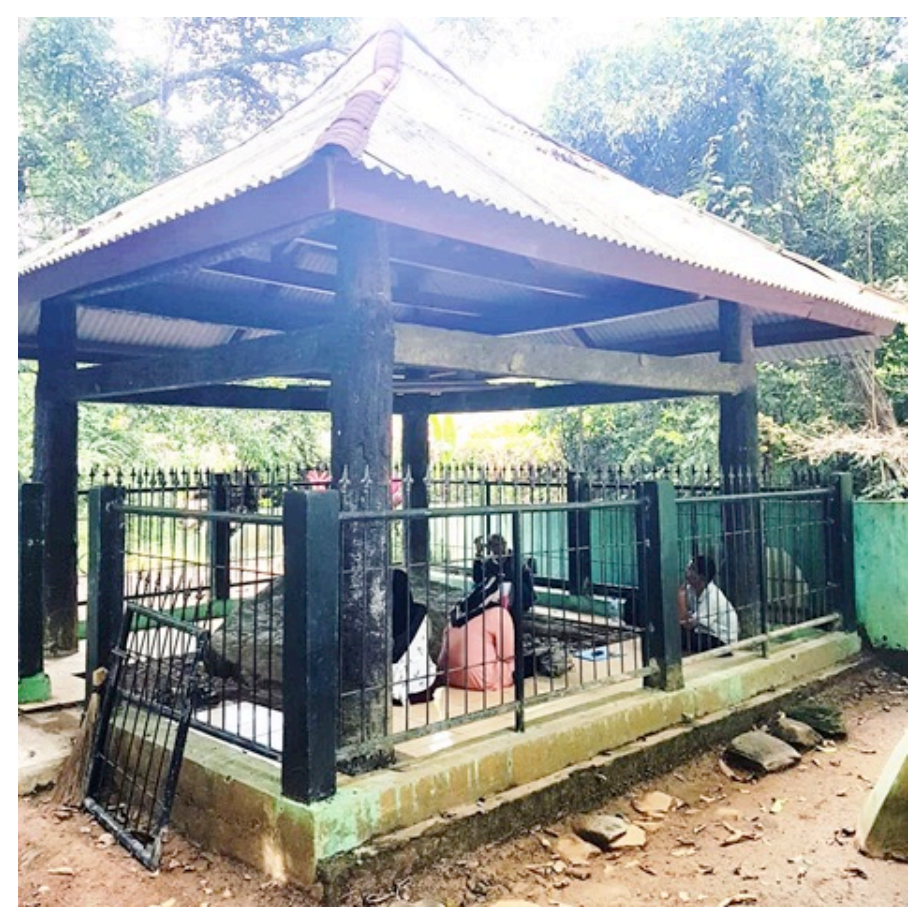

Gambar 8. Pagar Besi dan Pasangan Lantai Keramik di Sekitar Batu Prasasti (Sumber: Dokumen Mohammad Ali Fadillah, 2020). 
PURBAWIDYA: $\square$ Vol 10, No. 1, Juni 2021: 63-86 